Jurnal The Messenger, Vol. 10, No. 1, January 2018, pp. 34-43

P-ISSN: 2086-1559, E-ISSN: 2527-2810

DOI: $10.26623 /$ themessenger.v10i1.649

\title{
Cultural Identity and Social Interaction of Indigenous Peoples in the Middle of Modernization \\ (Case Study of Indigenous Peoples of Kasepuhan Banten Kidul)
}

\author{
Identitas Kultural dan Interaksi Sosial Masyarakat Adat \\ di Tengah Modernisasi \\ (Studi Kasus Masyarakat Adat Kasepuhan Banten Kidul)
}

\author{
Abdul Malik ${ }^{1}$ \\ ${ }^{1}$ Study Program of Communication Science, Universitas Serang Raya, \\ Jl. Raya Cilegon-Serang Km. 5 Drangong, Serang, Banten, Indonesia \\ *e-mail: kangdoel2002@gmail.com
}

\begin{abstract}
The indigenous community of Kasepuhan Banten Kidul is society entity that still maintains the past Sundanese traditions strictly, but is quite open and adaptive to the development of the age. The condition is reflected in their accommodative attitude towards all social changes that occur due to modernization. However, this condition does not make them lose their cultural identity as kasepuhan community. In the social interaction, the cultural identity is always inherent in them, both in the way of acting or reacting, and symbolized through the clothes and accessories worn. This condition can not be separated from the existence of indigenous institutions that have central role in upholding indigenous rules, so that all members of kasepuhan community have so strong ties to their cultural identity. Therefore, although in always changing social situation, they are able to adapt and even adopt the changes by not losing their cultural identity.
\end{abstract}

Keywords: Indigenous Community, Kasepuhan Banten Kidul, Cultural Identity, Interaction.

\begin{abstract}
Abstrak
Komunitas adat Kasepuhan Banten Kidul adalah entitas masyarakat yang masih ketat mempertahankan tradisi Sunda masa lalu, tetapi cukup terbuka dan adaptif terhadap perkembangan zaman. Kondisi tersebut tercermin dari sikap akomodatif mereka terhadap segala perubahan sosial yang terjadi akibat modernisasi. Namun demikian, kondisi ini tidak membuat mereka kehilangan identitas kulturalnya sebagai masyarakat kasepuhan. Dalam interaksi sosialnya, identitas kultural itu senantiasa melekat dalam diri mereka, baik dalam cara bersikap, bertindak, maupun yang disimbolkan melalui pakaian dan asesoris yang dikenakan. Kondisi ini terjadi tidak lepas dari keberadaan lembaga adat yang memiliki peran yang begitu sentral dalam menegakkan aturan adat, sehingga seluruh anggota masyarakat kasepuhan memiliki ikatan begitu kuat terhadap identitas kulturalnya. Karena itu pula, meskipun dalam situasi sosial yang terus berubah, mereka mampu beradaptasi bahkan mengadopsi perubahan tersebut dengan tidak kehilangan identitas kulturalnya.
\end{abstract}

Kata Kunci: Komunitas Adat, Kasepuhan Banten Kidul, Identitas Kultural, Interaksi.

Copyright (C) 2018 Universitas Semarang. All rights reserved.

\section{Introduction}

Social change is part of the dynamics that occur in society. Therefore there is no community that does not experience the change. Related to this, there are at least two classifications of community, namely static community and dynamic community. Static

Article History: Received October 30, 2017; Revised January 15, 2018; Accepted January 27, 2018; Published January 31, 2018 
community is community who have very little changes and tend to run slowly. While the dynamic community is community experiencing variety of rapid changes. About the typology of this static community, among others we can take example of the Samin tribe people in Blora, Central Java. Research conducted by Emmilia Vinna Octaviani (2015) mentions that modernization does not necessarily bring changes in their attitudes and behavior. On the contrary, despite being faced with the swift currents of modernization, they remain firm to the principles and teachings of life they embrace. Not in school, dressed all in black and not wearing sandals.

Based on that, then the various changes that happen in society can be in the form of progress and can also mean setback from certain areas of life (Soekanto, 2009: 260). Samuel Koenig (in Soekanto, 2009: 263) states that social change refers to the modifications happening in the patterns of human life that occur due to internal causes or external causes.

Based on the definition, social change is something that can not be denied, including by indigenous peoples. Similarly, it happens to indigenous peoples of Kasepuhan Banten Kidul who live and spread in the area of Lebak Regency in Banten Province, Sukabumi, and Bogor in West Java Province. They are indigenous peoples calling themselves Kasepuhan Indigenous Unity or also called Kaolotan Banten Kidul. They have similarities, among others are on the aspect of history, derived from the same tribe and culture, namely Sundanese tribe and culture, including the same offspring (incu putu). The indigenous community of Kasepuhan Banten Kidul also have their own culture, encompassing all the unique set of values and behaviors. They have their own distinctive attributes and identities through both verbal and nonverbal languages, including certain symbols, even rituals like traditional ceremonies, and so on.

The term "kasepuhan" is derived from the word "sepuh" with prefix "ka-" and suffix "-an". "Sepuh" is synonymous with the word "kolot" in Sundanese, which means old. Thus the title of "kasepuhan" or "kaolotan" refers to the leadership system of a community or social group in which all members' activities are based on the customs of the parents. Thus, the meaning of "kasepuhan" here means old customs or ancestral customs. It is this custom that underlies them to keep strengthening the bonds of kinship with their descendants and to call themselves as the indigenous unity of Banten Kidul which in Sundanese is called "tatali paranti karuhun" (Ruby and Wachyudi: 130). Aliansi Masyarakat Adat Nasional (AMAN) defines indigenous peoples as hereditary community group residing in certain geographical regions of the country of Indonesia due to ties to ancestral origins, strong links to the land, territory and natural resources in their indigenous territories, as well as the existence of value system that determines different economic, political, social and legal institutions of society (http://yancearizona.net/tag/masyarakat-adat/; accessed on August 5, 2017 at 09.10 WIB). While based on socio-cultural reality in Indonesia, indigenous peoples entities can be classified into four typologies.

First, local community group who still adhere firmly to the principle of "earth hermit" by not changing the way of life such as the tradition of farming, dressing, consumption patterns, and so on. They still exist by not having contact with outsiders. They also choose to preserve the natural resources and the environment with their local wisdom. Second, local community who are still strict in maintaining and implementing customs, but still open enough room for transactional relationship with outsiders. Third, indigenous peoples entities who live depend on nature (forests, rivers, mountains, seas, etc.), and develop unique natural resource management systems, but do not develop 
strict customs for housing and selecting the types of crop if compared to community in the first and second group. Fourth, indigenous peoples entities who have been uprooted from the "original" natural resource management arrangements as a result of colonialism that have grown hundreds of years (in Siradjudin, 2010).

The indigenous community of Kasepuhan Banten Kidul belongs to the typology of the second indigenous group of entities, i.e as people community who still maintain strict Sundanese traditions of the past, but they are quite open and adaptive to the development of the age. According to the typology, the social changes in Kasepuhan Banten Kidul society are quite dynamic, and therefore, in their various social activities, their contact with the things of modernization is inevitable.

In the use of agricultural tools, the people of kasepuhan are now accustomed to using tractors. Similarly in the social life activities, they are accustomed to utilizing various technologies. For example, almost every home in Kasepuhan area has satellite dish that allows them to access various domestic and abroad television broadcasts. Likewise in terms of social interaction, they are accustomed to utilizing communication technology such as mobile phones for the benefit of communicating. Including in terms of dressing and social intagection, they are known as fashionable indigenous peoples because they usually wear clothing worn by city or urban communities. In this context modernization is type of social change that is interpreted as the changes of society moving from the traditional or pre-modern to the modern society.

However, this condition does not make them lose their cultural identity as kasepuhan society which is characterized by its adherence to various customs rules. They also still maintain various traditions and indigenous rituals that have lasted since centuries ago.

Similarly, in the social intagection that they intertwine, the cultural identity is always inherent in them, both in the way of acting, reacting, and being symbolized through the clothes and accessories worn. In fact, social changes due to modernization often have implications for the erosion of the cultural identity of a society. The research conducted by Wega Dwi Rafika and Bambang Samsu on "Perubahan Sosial dalam Masyarakat Adat Tenganan Pegringsingan" (2013), for example, shows that due to the rapid flow of tourism development in Bali, indigenous peoples begin to lose their cultural values characterized by the changes of lifestyle, thought, and job migration from people working in agriculture to working in tourism sector.

In relation to the issue, this study is focused to study; First, how the kasepuhan community maintains its cultural identity amid the rapid flow of social changes due to modernization. Secondly, how the people of kasepuhan intagect with the community outside kasepuhan.

Conceptual Basis

\section{Cultural Identity}

Cultural identity can be defined as the breakdown of characteristics or the characteristics of a culture owned by a group of people that we know the boundaries (bonded) when compared to the characteristics or cultural traits of others (Liliweri, 2005: 41-42). Thus, when we want to know and to understand, even to set someon's cultural identity, we can not simply determine the characteristics or physical / biological characteristics of the person concerned, but we need to examine the cultural identity of the person through the order of thinking, feeling, and how to act. While Kenneth Burke (in Liliweri, 2005: 42) simply says that to determine someone's cultural identity depends 
on language because language representation can explain a fact of all the identities specified and then compared.

In relation to the issue of cultural identity, Marry Jane Collier successfully developed a theory called Cultural Identity Theory. This theory was developed to understand how the process of communication was done to build and negotiate the identity of cultural groups and the relationships in certain contexts.

According to Collier, identity is formed on the basis of communicative intagection with others and messages conveyed by someone when intagect with others can contain various cultural identities such as race, ethnic, ethnicity, social class, and various other things.

Collier and Milt Thomas (in Gudykunst, 2005: 239-240) further formulated seven basic traits of cultural identity. First, individuals have various cultural identities that may arise in behavior, including citizenship, race, ethnic, social class, gender, political choice, religion, and others. Cultural identity exists when the behavior patterns of all individuals show the identity of their membership in group or groups. Second, from individual perspective, this diverse cultural identities differ according to the situation and also vary over time and intagection. Third, cultural identity varies within certain scope, referring to how widely "held" and genagelized they are. Fourth, cultural identity is formed through the process of recognition (self concept) and assumption (view by others). Fifth, the intensity at which particular identity is recognized and perceived differently depends on the situation, context, topic, and relationship that exists. Sixth, cultural identity survives through time and space, and changes significantly. Seventh, cultural identity has two aspects both content and relational.

Thus, when someone assesses or sees someone or group based on his cultural identity, he must understand that the identity of the group is basically the result of the thought of the individuals in the group. In addition, someone who intagects must also understand that each individual can have more than one identity. It depends on the role that is being done. Because of this complex cultural identity, there is potential for conflict to occur, so that if one wants to avoid a problem in intagecting, it is better to improve his ability in intercultural communication.

2. Social Interaction

Human life as social being can not be separated from the relational relationships with other human beings that manifest in social interaction. Gillin and Gillin (in Soekanto, 2009: 55) called social interaction as dynamic social relationships, which concerns person-to-person relationships, between groups of people, and between person-to-person and groups of people.

On the basis of the understanding, then social interaction will only be established if it meets two conditions, namely the existence of social contact and communication. What is meant by social contact is early action that result in communication, either through physical contact or mediated contact with communication technology and others. With the establishment of this social contact then communication is possible to take place. Ditha Prasanti and Sri Seti Indriani (2017) in their research entitled "Interaksi Sosial Anggota Komunitas Let's Hijrah dalam Media Sosial Grup Line", stated that social interaction that took place through social media had an impact on intense communication, had positive impact for the members, although in some cases it also had negative impact, especially on the emergence of debates that occurred in the discussion.

Jurnal The Messenger, Vol. 10, No. 1, January 2018, pp. 34-43 
In the perspective of social interaction, the communication that can be interwoven in such a way brings the consequences of mutual influence. The nature of communication itself is between the parties that interact will react to each other by giving interpretations for what they communicate (talk). With communication, the attitudes and feelings of a group of people or individuals can be known by other groups or other people.

In the perspective of social change, communication that exists as a type of social interaction, will bring influence to social change in society, both positive and negative impacts. Because, in the process of communication it is possible to the existence of associative and dissociative actions (Soekanto, 2009: 65-97).

Associative intagection is in the form of: (1) coopagetion, namely the joint effort between individuals or group of people to achieve one or sevagel common goals; (2) accommodation, that is a balance (equilibrium) in the interaction with social norms and social values prevailing in society. It can also mean action to defuse a contradiction, i.e efforts to achieve stability.

While dissociative interaction is in the form of: (1) competition, namely the social process in which the competing individuals or groups of people seek profit through various areas of life; (2) contravention, namely the form of social process that exists between competition and contradiction or conflict.

\section{Methodology}

The method used is case study method in the form of single case design. This is in accordance with the study conducted, in which the object under study is indigenous peoples in relation to their social interaction and cultural identity. This type of research, as Yin puts it, fulfills the prerequisite as a single case study because it is both unique and typical or represents similar case to other indigenous peoples. In a qualitative cluster approach, case study steps for data collection are inseparable from the genagel characteristics shown in qualitative research. Data in the context of this study is divided into primary and secondary data sources. Primary Source is an object or original document in the form of raw material from the main perpetrator referred to as first-hand information. The data collected at this primary source come from the actual live situation when an event occurs (Silalahi, 2006: 266), both based on interviews and observations.

The second data source is secondary data source where the data collected come from second-hand or other sources that have been available before the research is conducted (Silalahi, 2006: 266). For the determination of informants in this study, the technique used is purposive sampling, i.e based on the objectives to be achieved by researchers. Then, to obtain data in this study, it is started by determining key informants, who understand well the problems to be studied and can provide various information and data needed. A good informant is an informant who is able to capture, understand, and meet the researcher's request. Therefore, he must have reflective skills, take time for interviews, be eager to participate in research, and at the same time have wide knowledge of the issues studied (Sudikan, 2001: 91).

\section{Result and Discussion}

1. Traditional Efforts Maintain Cultural Identity

Indigenous peoples of Kasepuhan Banten Kidul embraced Islam by still practicing the "karuhun" traditions or customs, that is to run the tradition of forefathers or 
ancestors. However, they also recognize state law such as act or other government regulations. Therefore, the indigenous peoples of Banten Kidul are regarded as distinctive societies, because they are able to integrate the rules of tradition, religion, and government rules in the conduct of their lives.

The three blends are summarized in their terms called "Tilu Sapamilu, Two Sakarupa, Hiji Eta Keneh". This phrase is interpreted as "three one face or concurrent, two similar, the one is too", which means that, although there are many desires and various characteristics and attitudes, the essence is that man comes from an essential origin, that is Allah Subhanahu Wa Ta'ala. The phrase may also be construed as follows; "Tilu Sapamilu" is religion, tradition, and government that must go hand in hand. "Dua Sakarupa" i.e tradition and religion must go hand in hand parallelly. While "Nu Hiji Eta Keneh" means all must refer to the Negara Kesatuan Republik Indonesia (NKRI). It is this phrase which then teaches the indigenous peoples the concept of balance or harmony in life, i.e among religion, tradition, and obligation as citizen.

Maintaining cultural identity as a society that still holds the ancestral tradition is not without challenges. Especially in the swift flow of social change, which enables the erosion of their identity. As indigenous peoples who live dynamically and adaptively with the age, they also intagect with communities outside of their communities to allow for negative influences of modernization to their communities. The use of various electronic devices and communication technology, is something they can not resist as the consequence of the open interaction.

Such conditions are quite realized by kasepuhan community. They are aware that the rapid flow of modernization if not anticipated can threaten their cultural identity as indigenous peoples. In that connection, the people of kasepuhan have custom institutions that serve to remind, confirm and preserve their cultural identity. Custom institutions are local wisdom in the form of advocates and pikukuh customs (norms and customs rules), either in the form of prohibitions or taboos that should not be violated, traditional ceremonies, as well as obedience and submission to the traditional chairman.

Therefore, in everyday life the people of Banten Kidul adheres firmly to the traditions of "karuhun" that are passed down through "olot" or traditional chairman. In their tradition, for example, there are some rights and obligations that must be obeyed by "incu putu" (grandchildren), such as the obligation to return to hometown during "seren tahun." The decision on the obligation to return to hometown in this traditional activities is made as the customs effort to strengthen the relationship between community families as well as reaffirming its cultural identity.

Through "seren taun" traditional ceremony activity they are reminded about the nature of selfhood as kasepuhan society who believe that life is a born-life-death process that then eventually leads to an eternal phase. This is in accordance with the proverb of the society i.e "dug hulu pet nyawa conggeang balik aseupan", meaning people must be aware of the impossibility in this mortal life. The point is that basically human life can not be separated from the fulfillment of worldly needs, which although eventually will be abandoned when they are dead. The fulfillment of the needs here is not far from the fulfillment of clothing, food and housing, all of which are from earth / land. Therefore, they are very respectful to the land, as the place for the growth of rice, the source of human food. Based on this too, indigenous peoples always try to maintain harmony among human, nature and God expressed in various forms of events or socalled traditional ceremony as the form of gratitude.

Jurnal The Messenger, Vol. 10, No. 1, January 2018, pp. 34-43 
On the other hand, as a society that adheres to the past Sundanese customs and traditions, they must also always be bent in submission and obey all the traditional chairman's advices. In the cosmology of kasepuhan community, the traditional chairman poeition is considered sacred because it is only derived based on the genealogical relationship and based on divine inspiration. Therefore, the figure of traditional chairman in the concept of the local community is human figure of choice with all the advantages, both visible and beyond the minds of the ordinary people. Related to that, then all things should always be consulted to the traditional chairman, starting from planting time, naming a newborn child, when going to marry off their son or daughter, and so on.

The adherence of the community to what become custom rules manifested through submission and obedience to the traditional chairman because of the beliefs about "mamala" or in other terms is "pamali" or abstention, which if it is broken can lead to calamity such as accidents, diseases, and other calamities that can cause the loss of lives. "Here there is the term of mamala, we are afraid if we do not obey what Abah said," said the participant named Henriana Hatra (interview on September 13, 2013). 2. Social Interaction of Kasepuhan Community

In contrast to other indigenous communities such as the Baduy people who tend to isolate themselves, indigenous communities in Banten Kidul are open and dynamic indigenous communities. They are people who are adaptive to the development of the age and social changes. The evidence of how adaptive they are, it is seen from their lifestyle that follow the developmrnt of the age. Similarly, the social interaction that they intertwine, very dynamic and even able to cross the boundaries of the structure and culture of kasepuhan community itself.

In terms of language, although the language commonly used by the people is Sundanese, they are quite fluent in speaking Indonesian, even infrequently among young people use slang as young people in genagel. They are quite able to adapt in interacting and communicating with outside communities.

Another effect of the intagection that occur is on how to dress. In the social interaction, both with kasepuhan community fellow and with society outside kasepuhan, they usually wear modern clothes, even the type and brand of clothing used is not less modern with the urban community. However, despite their modern dress they do not leave their cultural identity as indigenous peoples. The identity, among others can be seen from the use of batik cloth as headband.

While in the custom activities, they always wear complete custom cloth called "tikim." Their custom cloth is made up of two colors, black and white, which they call "tikim hideung" and "tikim bodas." "Hideung" (black) means intelligent, fast, and understand. While the "bodas" (white) means sacred and clean. They mix "tikim" with the use of headband from batik cloth. They call it "iket", which means bound, has been bound as citizen of unity. For kasepuhan community, the headband has the meaning that humans using "iket" are human beings who are careful in acting. "Caricing pageuh kancing, saringset pageuh iket" which means standby and alert (Yoki Yusanto et. al., 2014: 91-92).

According to Henriana Hatra, the secretary of Kasepuhan Cisungsang, the use of headbands by kasepuhan community both in kasepuhan and outside kasepuhan is intended not only to show their cultural identity, but also to symbolize that in interaction with anyone they remain bound by the norms of custom rules. Because the triangular folded headband has the meaning of the adherence of the community to the custom, 
religion, and state rules (tilu sapamilu, dua sakarupa, anu hiji eta keneh). Therefore, the indigenous peoples should not violate these three rules in the interaction.

Meanwhile, in terms of technology, most indigenous peoples have used various electronic devices such as mobile phones with the latest technology, television, parabola, refrigagetor, and various other electronic devices as the result of social interaction that is intertwined with people outside the indigenous community. Even many of those who have both two-wheeled and four-wheeled vehicles. In addition to being open and adaptive to the development of the age, such lifestyles are also supported by their economic factors that increase along with the gold mining activities. The existence of gold mining is admitted by the community greatly boosted their livelihoods, so with their income - if they were lucky enough to get gold - they could buy various secondary necessities.

Likewise in terms of entertainment, kasepuhan community is an open society to all kinds of entertainment, both traditional and modern. In every custom activities such as "seren taun", kasepuhan community usually holds various kinds of entertainment, ranging from dangdut to pop music by bringing guest stars. This condition, of course, invites public interest from outside kasepuhan to come to visit which resulted in the establishment of such relational relationships (social interaction) with kasepuhan community.

Although open and highly adaptive to all the development of the age and social changes, in its social interaction kasepuhan community still do not abandon their cultural identity as indigenous peoples. This is confirmed by Secretary of Kasepuhan Cisungsang Henriana Hatra. According to him, "Life can be style, but lifestyle must remain based on custom rules. That's the principle of young people here, in kasepuhan. So we are not obsolete. But custom traditions must be maintained" (interview on September 19, 2014).

In the perspective of social interaction, social change (including social behavior change) in kasepuhan community as presented in the above explanation, is a type of accommodative interaction that is done consciously for the benefit of establishing equilibrium. Furthermore, it can be interpreted as a type of self adjustment to the development of the age and the advancement of various technologies that are impossible to be rejected by indigenous peoples.

About the accommodative custom attitude in social interaction and the impact of social change are confirmed by the traditional chairman. According to him, the development of the age and the increasingly sophisticated communication technology, can not be dammed by custom, except by being adaptive and accommodative. Therefore, he is not worried that the condition will bring negative impacts to the erosion of the cultural identity of kasepuhan community, because until now the norms and custom rules are still run by the people.

In this case, custom has its own way in anticipating the impact of the relational relationship of kasepuhan community with the outside community. Among others, through various custom rules and norms that must be followed and performed. Including through various types of custom rituals that serve to bind kasepuhan community awareness of their cultural identity. Therefore, the obedience and submission of kasepuhan community to custom rules is an obligation that can not be negotiable. "What is the meaning of custom rule if it is not obeyed and implemented."

For custom, as long as it is within the limits of fairness and not violating custom rules, then all changes that happen and social interactions woven, are still possible to be 
accepted. However, through custom institutions owned, custom always reminds the limits and fairness, and the consequences that will be got if there is violation, in the form of disaster that can cause death. As for those who commit the violation, then the concerned must perform "lukun" (a kind of confession of sin) that has been set by custom. "Lukun" is divided into 3 (three) stages according to the custom law which is violated, namely (1) "Lukun Lima", i.e if someone commits small sin (as custom rules), the person must worship the traditional chairman/abah five times accompanied prayers; (2) "Lukun Tujuh", i.e if someone commits mediocre act/sin (as custom rules), the person must worship the traditional chairman/abah seven times accompanied prayers; (3) "Lukun Salapan", i.e if someone commits big act/sin (as custom rules), the person will get such heavy punishment even until he dies if he does not immediately perform "lukun salapan."

\section{Conclusion}

In the midst of the rapid flow of social changes due to modernization, the indigenous community of Kasepuhan Banten Kidul are still able to maintain and preserve their cultural identity. This condition can not be separated from the existence of custom institutions that have central role in upholding custom rules, so that all members of kasepuhan community have so strong ties to their cultural identity. Therefore, although in always changing social situation, they are able to adapt and even adopt the changes by not losing their cultural identity as indigenous peoples who remain subservient and obedient to custom advices or "pikukuh" (custom norms and rules). Even in establishing social interaction with people outside kasepuhan they are able to maintain their cultural identity.

\section{Acknowledgement}

The writer thankful to Indigenous Peoples of Kasepuhan Banten Kidul who have given access to the writer to conduct this research.

\section{References}

Baedhawy, R.A., dan Wachyudin, N. (2013). Nilai-nilai Kearifan Lokal dalam Pelestarian Lingkungan Hidup Masyarakat Baduy dan Kasepuhan Cisungsang. Serang: Dinas Kebudayaan dan Pariwisata Provinsi Banten.

Gudykunst, W.B. (2005). Cross-Cultural and Intercultural Communication. London: Sage Publications.

Liliweri, A. (2005). Makna Budaya dalam Komunikasi Antarbudaya. Yogyakarta: LKIS.

Octaviani, E.V. (2015). Pola Komunikasi Suku Samin di Kabupaten Blora terkait Ajaran yang Dianutnya. Jurnal The Messenger, 7 (2), 26-29.

Prasanti, D., Indriani, S.S. (2017). Interaksi Sosial Anggota Komunitas Let's Hijrah dalam Media Sosial Grup Line. Jurnal The Messenger, 9 (2), 143-152.

Rafika, W.D., Samsu, B. (2013). Perubahan Sosial dalam Masyarakat Adat Tenganan Pegringsingan. Retrieved from repository.unej.ac.id/bitstream/handle/123456789/.../Wega\%20Dwi\%20Rafika.pd $f$ ?.

Silalahi, U. (2006). Metode Penelitian Sosial. Bandung: Unpar Press.

Siradjudin, A. (2010). Pengakuan Masyarakat Adat dalam Instrumen Hukum Nasional. Sulawesi Tengah: Yayasan Merah Putih. 
Soekanto, S. (2009). Sosiologi Suatu Pengantar. Jakarta: Raja Grafindo Perkasa. Sudikan, S.Y. (2001). Metode Penelitian Kebudayaan. Surabaya: Citra Wacana.

Yusanto, Y., et.al. (2014). Kasepuhan Cisungsang, Komunikasi Intrabudaya. Serang: Pustaka Getok Tular.

http://yancearizona.net/tag/masyarakat-adat/ 